Rhinosinusitis with Nasal Polyposis 
Advances in Oto-Rhino-Laryngology

Vol. 79

Series Editor

Patrick J. Bradley Nottingham 


\section{Rhinosinusitis with Nasal Polyposis}

Volume Editors

Bradford A. Woodworth Birmingham, Ala.

David M. Poetker Milwaukee, Wis.

Douglas D. Reh Baltimore, Md.

38 figures, 30 in color, and 9 tables, 2016

With a foreword by David W. Kennedy, Philadelphia, Pa. 

I dedicate this book to my wife and children whose love and support have provided me a constant source of inspiration.

Bradford A. Woodworth, MD

I dedicate this book to my parents for giving me the foundation I needed, to my wife for her constant love and support, and to my trainees for helping me continue to learn.

David M. Poetker, MD

I would like to dedicate this book to my father, David, who taught me the value of hard work, to my mentors for their training and constant guidance, to my residents and fellows who continue to help me discover and grow, and to my wife for her constant support.

Douglas D. Reh, MD 
Bradford A. Woodworth, MD

James J. Hicks Professor of Otolaryngology

Department of Otolaryngology - Head and Neck Surgery

University of Alabama at Birmingham

BDB 563, 1720 2nd Avenue South

Birmingham, AL 35294 (USA)
David M. Poetker, MD

Associate Professor

Zablocki VAMC, Department of Surgery

Department of Otolaryngology and

Communication Medical College of Wisconsin

9200 West Wisconsin Avenue

Milwaukee, WI 53226 (USA)

\author{
Douglas D. Reh, MD \\ Associate Professor \\ Department of Otolaryngology - Head and Neck Surgery \\ Johns Hopkins Medicine \\ 601 North Caroline Street, 6th Floor \\ Baltimore, MD 21287 (USA)
}

\author{
Library of Congress Cataloging-in-Publication Data \\ Names: Woodworth, Bradford A., editor.| Poetker, David M., editor.| Reh, \\ Douglas D., editor. \\ Title: Rhinosinusitis with nasal polyposis / volume editors, \\ Bradford A. Woodworth, David M. Poetker, Douglas D. Reh. \\ Other titles: Advances in oto-rhino-laryngology ; v. 79. 0065-3071 \\ Description: Basel ; New York : Karger, [2016] | Series: Advances in \\ oto-rhino-laryngology, ISSN 0065-3071; vol. 79| Includes bibliographical \\ references and indexes. \\ Identifiers: LCCN 2016021979| ISBN 9783318058536 (hard cover : alk. paper) | \\ ISBN 9783318058543 (electronic version) \\ Subjects: | MESH: Rhinitis | Sinusitis | Nasal Polyps \\ Classification: LCC RF361 | NLM WV 335 | DDC 616.2/05--dc23LC record available at \\ https://lccn.loc.gov/2016021979
}

Bibliographic Indices. This publication is listed in bibliographic services, including Current Contents ${ }^{\circledR}$ and Index Medicus.

Disclaimer. The statements, opinions and data contained in this publication are solely those of the individual authors and contributors and not of the publisher and the editor(s). The appearance of advertisements in the book is not a warranty, endorsement, or approval of the products or services advertised or of their effectiveness, quality or safety. The publisher and the editor(s) disclaim responsibility for any injury to persons or property resulting from any ideas, methods, instructions or products referred to in the content or advertisements.

Drug Dosage. The authors and the publisher have exerted every effort to ensure that drug selection and dosage set forth in this text are in accord with current recommendations and practice at the time of publication. However, in view of ongoing research, changes in government regulations, and the constant flow of information relating to drug therapy and drug reactions, the reader is urged to check the package insert for each drug for any change in indications and dosage and for added warnings and precautions. This is particularly important when the recommended agent is a new and/or infrequently employed drug.

All rights reserved. No part of this publication may be translated into other languages, reproduced or utilized in any form or by any means electronic or mechanical, including photocopying, recording, microcopying, or by any information storage and retrieval system, without permission in writing from the publisher.

(c) Copyright 2016 by S. Karger AG, P.O. Box, CH-4009 Basel (Switzerland)

www.karger.com

Printed in Germany on acid-free and non-aging paper (ISO 9706) by Kraft Druck GmbH, Ettlingen

ISSN 0065-3071

e-ISSN 1662-2847

ISBN 978-3-318-05853-6

e-ISBN 978-3-318-05854-3 


\section{Contents}

IX Foreword

Kennedy, D.W. (Philadelphia, Pa.)

Differential Diagnosis of CRS/NP

1 Differential Diagnosis of Chronic Rhinosinusitis with Nasal Polyps

London, N.R. Jr.; Reh, D.D. (Baltimore, Md.)

13 Allergic Fungal Rhinosinusitis: The Latest in Diagnosis and Management Loftus, P.A.; Wise, S.K. (Atlanta, Ga.)

21 Aspirin Exacerbated Respiratory Disease

Fruth, K.; Gosepath, J. (Wiesbaden)

29 Cystic Fibrosis Sinusitis

Le, C.; McCrary, H.C.; Chang, E. (Tucson, Ariz.)

New Discoveries Regarding Etiology of CRS/NP

38 Influence of P-Glycoprotein Function on Chronic Rhinosinusitis/Nasal Polyps

Pathophysiology

Cheng, Y.S.; Bleier, B.S. (Boston, Mass.)

48 B-Cells and Antibody-Mediated Pathogenesis in Chronic Rhinosinusitis with Nasal Polyps Min, J.-Y.; Hulse, K.E.; Tan, B.K. (Chicago, III.)

58 Innate Lymphoid Cells: The Innate Counterpart to T Helper Cells

Padro Dietz, C.; Luong, A. (Houston, Tex.)

69 The Role of Innate Immunity and Aeroallergens in Chronic Rhinosinusitis

London, N.R. Jr.; Tharakan, A.; Ramanathan, M. Jr. (Baltimore, Md.)

78 Acquired Cystic Fibrosis Transmembrane Conductance Regulator Deficiency Cho, D.-Y.; Woodworth, B.A.; (Birmingham, Ala.)

86 Role of Vitamin D in Pathogenesis of Chronic Sinusitis with Nasal Polyposis Shahangian, A.; Schlosser, R.J. (Charleston, S.C.)

91 Taste Receptors in Upper Airway Immunity Carey, R.M.; Lee, R.J.; Cohen, N.A. (Philadelphia, Pa.) 
Advances in Medical and Surgical Therapy

103 Immunomodulators in the Treatment of Nasal Polyposis

Halderman, A.A.; Lane, A.P. (Baltimore, Md.)

114 Delivery of Topical Therapies

Smith, K.A.; Rudmik, L. (Calgary, Alta.)

121 Topical Steroids

Oakley, G.M. (San Francisco, Calif./Sydney); Harvey, R.J. (Sydney)

131 Implantable Devices/Drugs in the Management of Nasal Polyps Santarelli, G.D.; Han, J.K. (Norfolk, Va.)

138 Oral Therapeutics for Rhinosinusitis with Nasal Polyposis

Thomas, A.J.; Alt, J.A. (Salt Lake City, Utah)

148 Advances in Surgery: Extended Procedures for Sinonasal Polyp Disease Southwood, J.E.; Loehrl, T.A.; Poetker, D.M. (Milwaukee, Wis.)

158 Outcomes in Medical and Surgical Treatment of Nasal Polyps Jafari, A.; DeConde, A.S. (San Diego, Calif.)

168 Author Index

169 Subject Index 


\section{Foreword}

We are all aware that chronic rhinosinusitis (CRS) is not a disease but rather a pantheon of disorders that present with symptoms and signs, which fulfill a broad set of diagnostic criteria. In this book, the authors focus on one important, currently acknowledged phenotype with which we all wrestle in day-to-day patient management, namely, nasal polyposis. It is said that if you had only a limited number of nasal polyp patients in an otolaryngology practice, then the practice would continue to be busy as a result of the need for repeated surgeries. We are now beginning to be able to classify the disorders in this phenotype and to improve our understanding of it. It has been recognized for long now that eosinophilic polyposis responds better to steroids than neutrophilic polyps respond. However, as our knowledge of the nasal polyposis phenotype and many subtypes keeps evolving, we continue to learn that different subtypes of nasal polyposis benefit from varied therapeutic approaches and that armed with such knowledge, we can significantly improve patient outcomes. Endoscopic evaluation has enabled us to follow the disease, even when it is asymptomatic or minimally symptomatic, and manage polyposis with a variety of therapeutic options, without the need for frequent revision surgical interventions.

In this book, the authors provide important practical knowledge for treating physicians. This book also serves as an important academic update reference on nasal polyposis. Divided into three sections, the book covers differential diagnosis, new discoveries in etiology and advances in medical and surgical therapy. In the interest of focusing primarily on new knowledge, the authors elected not to include more established theories regarding polyp formation, such as the role of staphylococcal endotoxins, but do include newer areas such as the influence of P-Glycoprotein function, local immunity, vitamin D deficiency and acquired cystic fibrosis transmembrane conductance regulator deficiency, to name but a few. Sections on differential diagnosis, allergic fungal rhinosinusitis, AERD and cystic fibrosis sinusitis are of particular value to the practicing otolaryngologist, as will be the chapters on immunomodulators, topical therapies and advances in surgery. Sections covering the new discoveries in etiology are invaluable to the subspecialist, a resident preparing for the boards and academic otolaryngologists.

Nasal polyposis is at the forefront of a new era in which the many different manifestations of CRS and of nasal polyposis are appropriately classified and differentially managed. I congratulate the authors in compiling this informative volume and look forward to additional editions as our knowledge and our therapeutic options continue to further evolve.
David W. Kennedy
Rhinology Professor
Perelman School of Medicine
University of Pennsylvania
Philadelphia, Pa., USA 
